\title{
Ethnobiology and Health among the Kulina People from the Upper Envira River, State of Acre, Brazil
}

\author{
M. Haverroth", , P.R.M. Negreiros ${ }^{1,2}$ and L.C.P. Barros ${ }^{3}$ \\ ${ }^{I}$ Empresa Brasileira de Pesquisa Agropecuária (Embrapa Acre), Brasil; ${ }^{2}$ União Educacional do Norte (Uninorte), \\ Brasil; ${ }^{3}$ Universidade Estadual Paulista "Júlio de Mesquita Filho", Campus de Botucatu - SP, Brasil
}

\begin{abstract}
This article is about an ethnobiological and ethnoecological research among Kulina People from the Upper Envira River, located in the Amazon Region, State of Acre, Brazil. The data was collected during two work trips to 10 villages of three Indian Lands (IL) in 2008 and 2009. The field work was based on participant observation, open, semistructured and structured interviews and walk-in-the-woods technique. The total population was 423 distributed in 77 dwellings. The gender proportion is $49,7 \%$ of women to $50,3 \%$ of men. Fifty one per cent are under 15 years old. The most important health problems are respiratory and digestive signs and symptoms, dermatosis and ophidian attacks. Kulina diet is based on cultivated foods, hunt and fishes. There is a variety of fruits collected in the forest. The cultivation system has high biodiversity and is about 1 ha. We recorded 193 medicinal plants species to a large number of purposes. The number of species recorded, indications by Kulina about properties and potential uses to health for these plants indicate an important ethnobotanic knowledge and requires new researches among them. We calculate that a great number of species is yet to register.
\end{abstract}

Keywords: Ethnobotany, Amazon, Kulina, Soth American Indians, medicinal plants, Acre, Brazil.

\section{INTRODUCTION}

This article is fruit of a research among the Kulina (Madija) of the Upper Envira River, Municipality of Feijó, State of Acre, Brazil (Figs. 1 and 2). The State of Acre has a great potential in medicinal plants and high biodiversity, to higher than to other areas of the western Amazon [1]. In Acre, it has great potential in terms of medicinal plants, but few studies have been carried through in order to know the ethnobotany, especially relative to medicinal plants, and the great majority of these studies were carried out in Conservation Units [2-9]. These works show that the population knows a significant number of species with medicinal potential and they regularly make use for the most diverse purposes. Our research was authorized by Genetic State Management Council (CGEN) of the Ministry of Environment (MMA) of Brazil [10].

The Kulina living coverage begins in Peru until the proximities of the Solimões River and is differently distributed on Indigenous Lands (IL). In Acre, they inhabit, basically, in the Upper Purus River, in the municipality of Manoel Urbano and Santa Rosa dos Purus, on various Indian Lands (IL) throughout the Envira River, municipality of Feijó (IL Kulina do Igarapé do Pau, IL Jaminawa-Envira, IL Kulina do Rio Envira, and the IL Kaxinawá de Nova Olinda). The kulina language belongs to the Arawá family [11]. The Kulina speaks predominantly in the native language. Among the few bilingual, most are older men, which had co-existed with non-indians during the rubber stripping, before the IL demarcation.

*Address correspondence to these authors at the Embrapa Acre, Rodovia BR 364, Km 14 (Rumo Porto Velho), Caixa Postal 321, CEP: 69908-970 Rio Branco - AC - Brasil; Tel: 55 (068)3212-3219;

E-mail: Moacir.haverroth@cpafac.embrapa.br
The objective of this article is to present and to argue preliminary data of the kulina etnobiology, with emphasis in the knowledge and use of therapeutical and food resources (plants and animals) that have influence in the health of the Kulina. We will present a general picture of the main problems related with the health, as well as the sanitation, water supply and illnesses.

In dealing with "health" and "illness" among indigenous people, it is necessary to take in account the cultural context of each group. According to Langdon [12,13], what the people perceive as illness and the symptoms associates are modulated by the cultural system, conceives health and illness as psycho-biological and socio-cultural processes, as well as the taken curative actions, and the evaluations throughout the process. The illness is not seen purely like a corporal/biological process, but as the result of the cultural context and the subjective experience of not feeling well. Thus, we are considering not only the therapeutic resources, generically called remedy, but diverse factors that, of some form, influence the general state of "health" of the Kulina, such as food, water and sanitation. According to Pollock [14], the Kulina recognizes that the term "illness" (doença in Portuguese) can assign a wide range of organic disorders, but it does not have similar term in its language. This absence of a general classification for the diverse friction situations as "illness" is consistent with what can be labeled as práxis of the illness for the Kulina, that can be classified according to its causes and its treatments.

In our study, we follow the Toledo scope [15] and Cabrera et al. [16], according to which we must register the group cosmovision (kosmos), that is, system of beliefs, myths and rites that have relation with the environment; to describe the repertoire of knowledge concerning the natural way and that, generally, it is a knowledge not written, where 


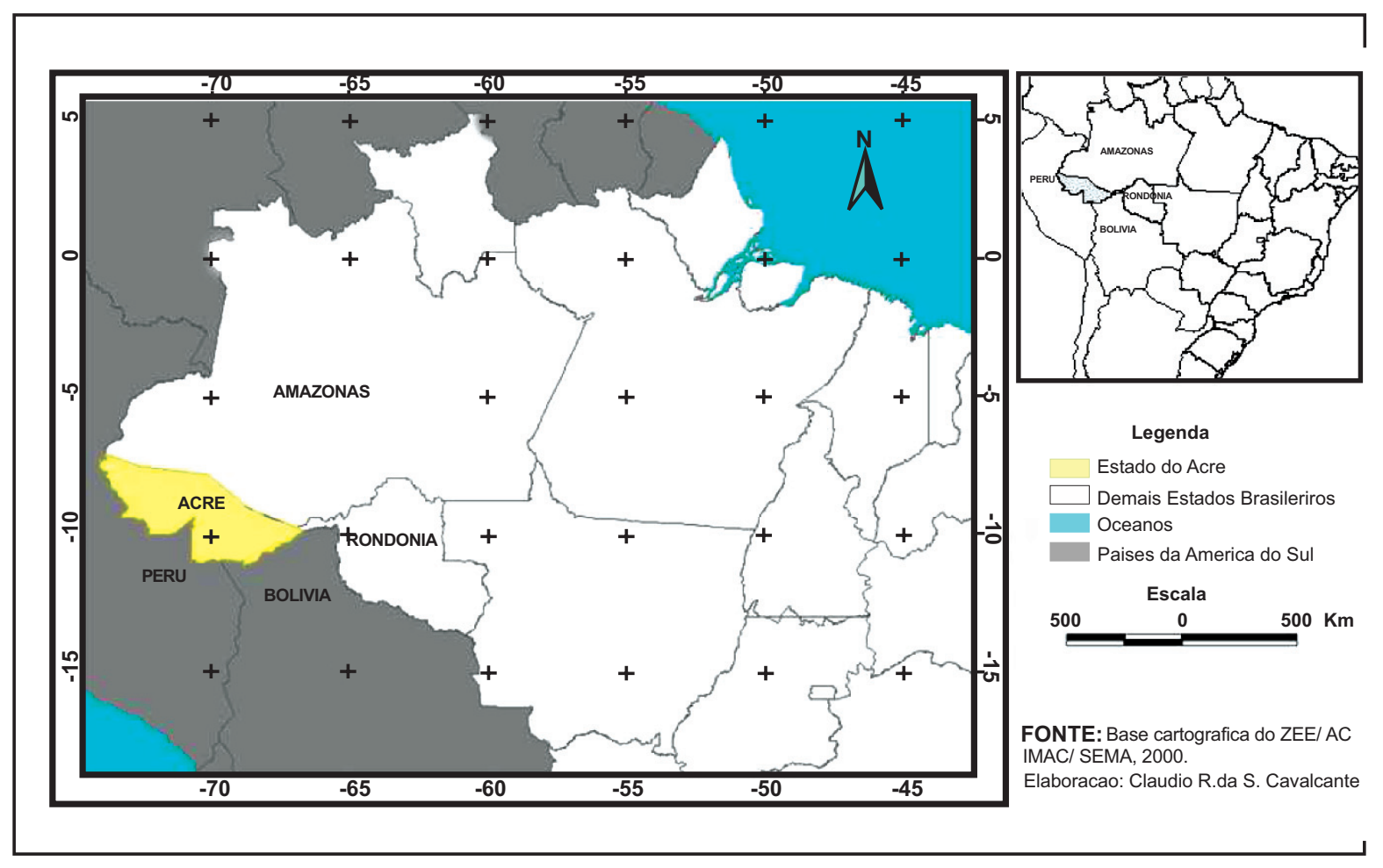

Fig. (1). Localization of the State of Acre in relation to other Amazonian States of Brazil and to Peru and Bolivia Countries.

more finds "the objective" portion concerning the natural way (corpus); to describe the set of practical productive and/or the extrativists that takes place during the natural resources appropriation and the effect of these practices in the ecosystem under the paradigm of the support (praxis). With regard to the aspects of the process health-illness, we follow the concept of intermedicality of Greene [17] in order to contextualize the use of plants with therapeutical and alimentary purpose inside the Kulina reality, well as aspects of shamanism. Greene suggests the notion of "intermedicality" - a contextualized space of hybrid medicines and sociomedically conscious agents - in South America. In this intermedicality context, various health services and actors (officials or not) are inserted, having interaction of ideas and actions in a dynamic context where the relations must be symmetrical.

In a context of rich biological and cultural diversity, case of Acre, the ethnobotany knowledge has great importance for Research and Development with medicinal, fitocosmetic and nutraceutic plants. The few studies in this direction in Acre show that the indigenous know and use many species, some cultivated, other handled in extrativist systems [18-21].

The traditional knowledge in this area is of great importance for the biotechnology, especially of pharmaceutical, chemical and agricultural products. Of 120 isolated active principles currently of superior plants, widely used in the modern medicine, $75 \%$ of them have utilities that they had been identified by the traditional systems of use [22]. Deriving data of the indigenous cultures can validate a vegetable drug and serve as source of research for new medicines [23]. With the increasing environmental and cultural changes, it has trend to the loss of important ethnobotanical knowledge, especially on medicinal plants.

According to degree of priority for conservation, sustainable use and distribution of benefits of the Brazilian Amazônia, the region of Envira River, Feijó (AC), object of this research, is considered an area of "high importance". With regard to the botany, this region is classified as area of "extreme importance" for having high species richness and endemism. All State of Acre presents low number of publications on ethnoknowledge, and the region of the Upper Envira River has no publication on this thematic [24]. Therefore, we have a framework that justifies this type of study: high biological and cultural importance and, practically, absence of research.

We use the term "Ethnoknowledge" in a conception of traditional knowledge of a specific population, with proper cultural origins and characteristics that distinguish it from others populations and are fundamental for its identity. We understand traditional populations as groups that pursue a public identity that includes some features, such as: use of low impact environment techniques, equitable forms of social organization, legitimate institutions to make to fulfill their rules, local leadership and cultural traits selectively reaffirmed and reworked [25]. Thus, we can define ethnoknowledge and, in this direction, traditional knowledge as being those that possess the indigenous peoples and local communities, transmitted from generation to generation and, habitually, by oral language and developed outside the formal education system or school. Ethnonowledge is 


\section{Mapa da região}

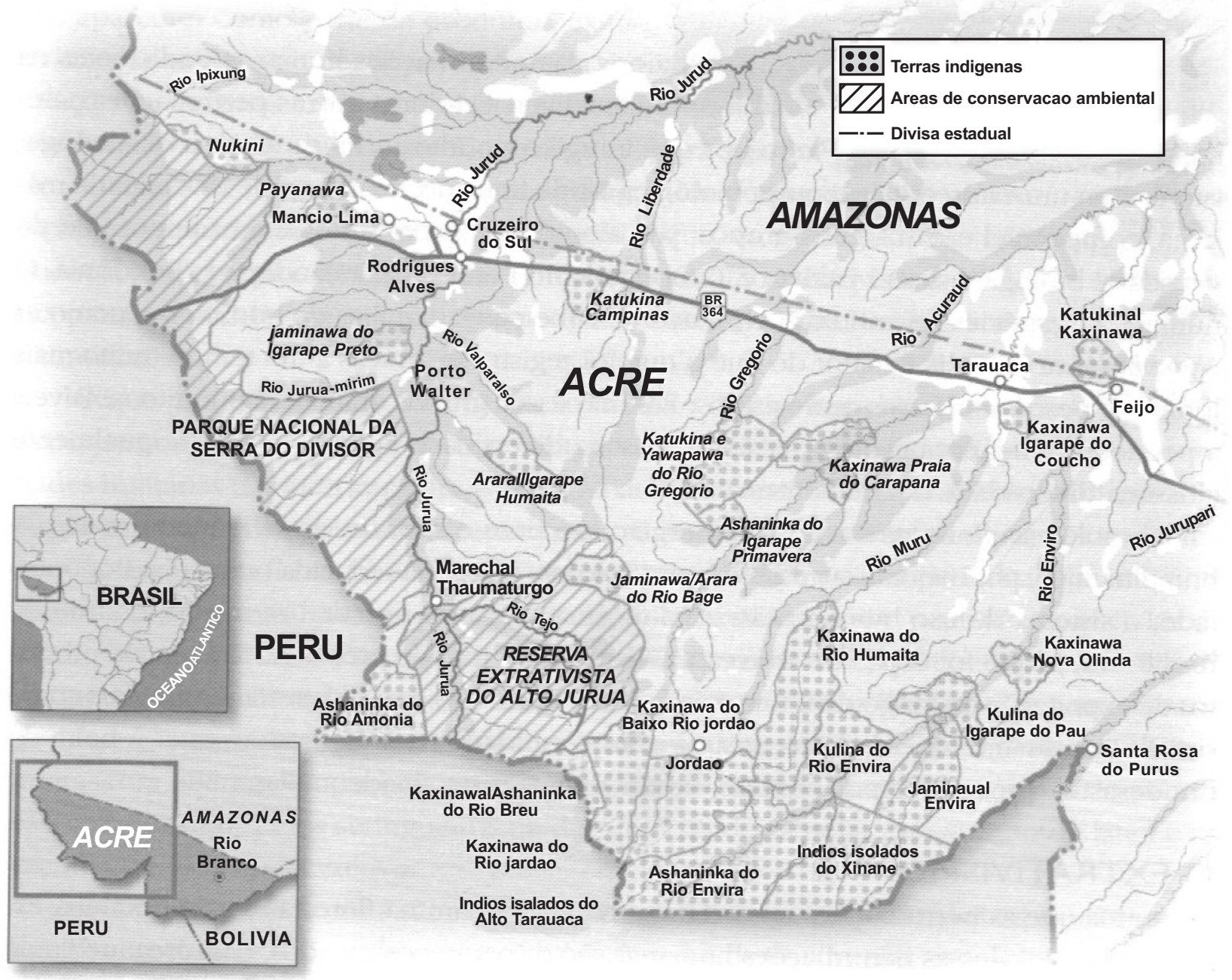

Fig. (2). Localization of Indian Lands Kulina do Rio Envira, Jaminawa-Envira and Kulina do Igarapé do Pau, in the Upper Envira River, State of Acre, Brazil.

dynamic, in constant process of adaptation and based in a structure of values, ways of life and mythical beliefs deeply rooted in the daily life of the indigenous peoples [26].

\section{MATERIAL AND METHODOLOGY}

\section{Researched Area and Population}

In the last 30 years have been recognized in the state of Acre 34 Indian Lands (IL) to fourteen peoples, with an area of $2,390,112.26$ ha ( $14.55 \%$ of the state), covering an overall population estimated at 12,720 Indians [27]. The field research was carried through in the Indian Lands (IL) Kulina do Igarapé do Pau (45.590 ha), Kulina do Rio Envira (84.365 ha) and Jaminawa-Envira (80.618 ha), located in the Upper Envira River, a tributary of the Juruá River, Municipality of Feijó, Acre State, Brazilian Amazon (Fig. 2). Both are inhabited by the Kulina People (Madija, Madihá), linguistic family Arawá, and some families of Ashaninka or Kampa, linguistic family Aruak. This research targets the Kulina group.
The Kulina lives, today, to a large extent, in the border of Brazil with Peru. In Brazil, they live in villages throughout the basin of the Jurua River and in the Upper Purus River, where they were around 2.500 individuals in 2002, being approximately 500 in the Peruvian side in 1998. In the Acre, they live, currently in five IL, all regularized. According to data of the Indian National Foundation (FUNAI) gotten in 2002, the Kulina of the Acre totalizes 1,737 individuals [28].

The population in the three IL of this project, in November and December of 2008, were 423 people, in 77 houses, distributed in ten villages. The occupation of the houses varies from 2 to 10 individuals. The ratio between gender is of $49,7 \%$ women for $50,3 \%$ men. A fifty percent has less than 15 years old. The population pyramid (Fig. 3) shows that there are few adults and the old ones are rare. This profile demonstrates a high tax of natality, but low life expectancy.

With regard to the age, in many cases, what is done is an approximation of date of birth due to lack of registration or other document. In these cases, we base on information from relatives. The date of birth does not have importance for the 


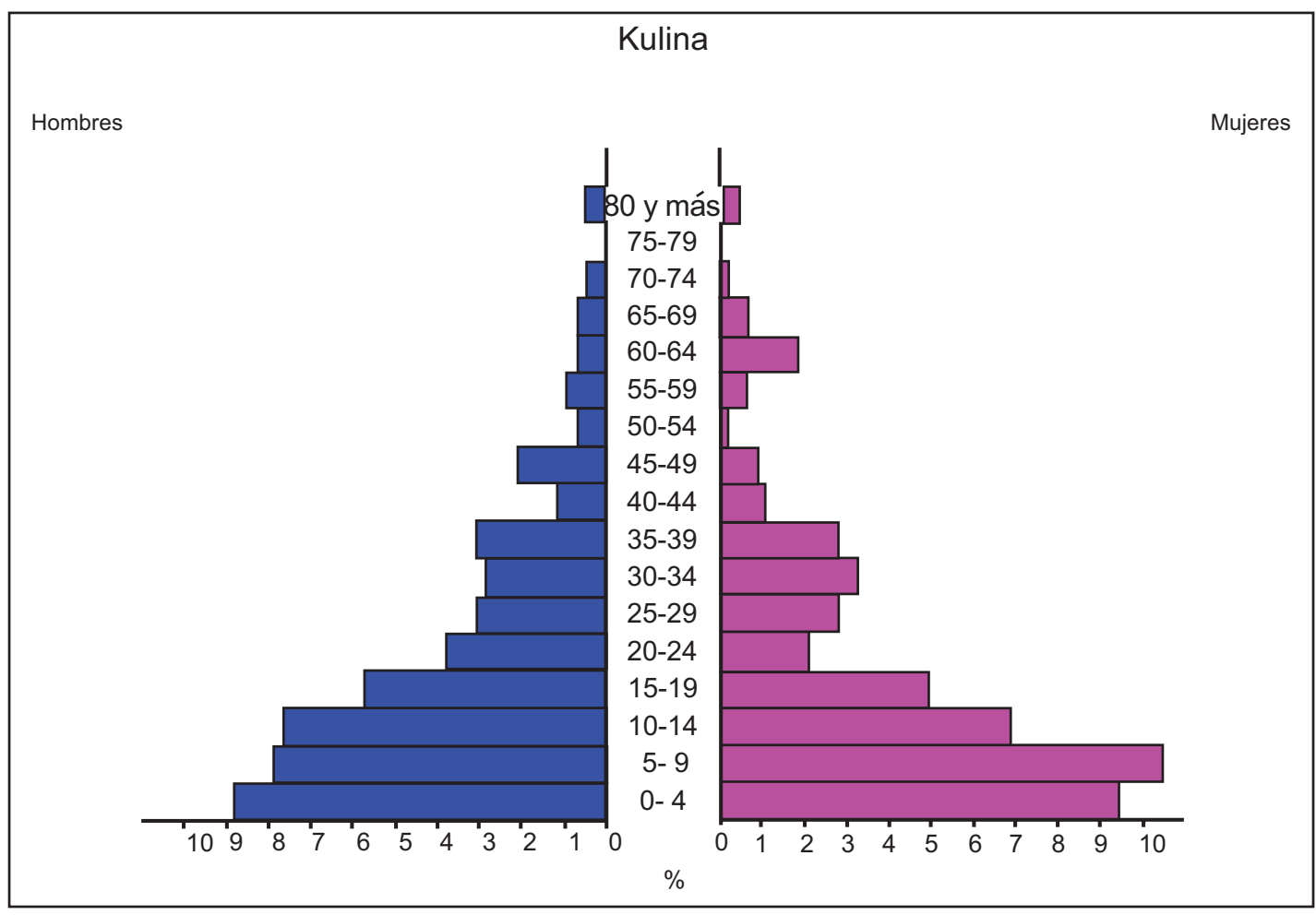

Fig. (3). Populational pyramid of Kulina People from IL Kulina do Rio Envira, Jaminawa-Envira and Kulina do Igarapé do Pau, in the Upper Envira River, municipality of Feijó, State of Acre, Brazil, December 2008, in percentage (n=423) (EPIDAT 3.1 Software).

Kulina, except when at the time getting the retirement, process that regular personal documentation demands. In function of this, it was not possible to register date of birth of four people, which were absent at the moment of the survey.

There is a strong imbreeding and some intergroup marriages, especially with the Kampa (Ashaninka), which also inhabit in this region of the Envira, and with white people (cariu). There are cases of bigamy, always a man with two women. In one of these cases, the two women are sisters. In another case, the older woman is kulina and the younger is kampa.

The research sample unit, in each village, is the housing or family. The villages are relatively small, and then the sample involved all homes in each village.

The IL Kulina do Rio Envira is located more to the south. After this, are located the IL Ashaninka do Rio Envira and the Isolated of the Xinane in the border with Peru. The population of IL Kulina do Rio Envira is distributed, basically, in two villages. Most traditional and located higher up is called "Igarapé do Anjo", with a population of 55 people, distributed in nine houses. Another village, called "Terra Nova", is subdivided in three, all located relatively close to each other, each one led by a brother. In the set, the three are inhabited by 86 people, distributed in 15 houses.

IL Jaminawa-Envira is located just below. There is an overlapping of a part of its area with the Santa Rosa do Purus National Forest. However, as all the kulina villages are in the edges of the Envira River, they do not explore in significant way this overlapping area. This IL possesses two villages. The main calls "Salão" and has 47 people in eight houses.
Second, more below, it calls the "Boca (mouth) do Jaminawa", exactly because it is located in the estuary of the Stream (igarapé) Jaminawa, limit of this IL. An extensive family with 21 people lives there distributed in five houses.

The IL Kulina do Igarapé do Pau is located more below. In this IL, it has six villages, being California the main one. Some names of villages are inheritances of old rubber-tree laden forest (seringais), when the region was the site of the extraction of latex of rubber-trees (Hevea brasiliensis ( $H B K$ ) M. Arg.), until the 1980 decade, when it began the process of landmark of the IL. In the California village, it has 68 people living in twelve houses. The other villages are: União, with 34 in seven houses; Limoeiro (chief Manoelzinho), with 17 people in four houses; Limoeiro (chief Expedito), with 24 people in five houses; Coqueiro, with 43 people in eight houses; and Santa Julia, with 28 people in five houses.

The population and occupation are dynamic. There are constant changes of families from one village to another one due to internal conflicts, very common among the Kulina, or due to occupation of new areas for cultivation. The birth rate was relatively high, as we can perceive in the population pyramid (Fig. 3). In recent years, with the consolidation of the domain of the IL, the majority of the indigenous peoples, included the Kulina, has increased its population in a rate above of the non-Indian population in Brazil.

Despite the lack of a more accurate knowledge about the Amazonian biodiversity, available information suggests a high variety of species to the region of Acre State. The western Amazon is considered by some researchers a region of high priority for biodiversity conservation [27]. The Upper Envira River is between Upper Purus and Tarauacá 
Rivers. This region is covered by tropical rain forest alluvial [24], that it is a type of forest that occurs throughout the watercourses ocupying the terraces of quaternary plains [29]. It consists of species that reach 50 meters of height, fast growing, generally with smooth bark, tapered trunk and tabular roots. There are many palms in the dominated extract and the sub-grass, with species that do not exceed five meters. There are some non-ligneous plants at the soil surface, presents many herbaceous and woody vines, in addition to great numbers of epiphytes [30]. Purus and Tarauacá-Envira Rivers are the sub-regions of State that present the lesser-known terms of its flora [27].

\section{Procedures}

Two field trips had been made. The first one was between November 8 and December 13, 2008. The second was between April 13 and May 26, 2009. The focus of the two first field trips (2008 and 2009) had been more general surveys in population terms, general conditions of health and sanitation and availability of alimentary resources from croping, hunting and fishing. The record of forest plants for therapeutic use would be made only preliminarly, thus it was limited to some villages (Igarapé do Anjo, Salão e União) where the conditions of time and availability of the inhabitants had been more favorable. Thus, the information on medicinal plants of the forest is not yet complete.

The field research consisted of direct and participant observation, opened, semi-structured and structured interviews [31-33]. The open interviews had an exploratory purpose at the beginning of the fieldwork and were led by guide emic. This situation starts with part of a generic question and then, the questions are generated from each gotten reply. The semi-structured interviews were based on a script-guide previously elaborated concerning a subject related with the objectives. The structured interviews had been used only for the population survey. The technique walk-in-the-woods was used [31], always with one or some informants of the community, which pointed out plants, cite its names and uses or validate names of plants cited in the interviews. The free list was used aiming to search specific information on a cultural domain, for example, medicinal plants that they know. The mapping communities were made aiming at to congregate information concerning the natural resources and of the local perception in a geographic context, including zones of resources, with the collaboration of Kulina to illustrate the villages and their surroundings in sketch maps. The botanical collecting methods, processing and identification of samples will be made in the 2010 trips. This is justified by the fact that we did not find appropriate conditions for collecting samples in the first two trips. During the first visits, the incursions for the woods were carried out in order to get a general framework of the ethnobotany knowledge. The walking speed and volume of information about many plants made the work of collecting unfeasible of the practical point of view. Ahead of this, we opt to reserving the two trips foreseen for the year 2010 for incursions specifically directed to the collection of samples of the plants, since the visited places are well defined and concentrated in three villages. One factor that makes it much difficult to collect data in this region is the weather, sometimes very hot and sunny, sometimes torrential rain, as field trips can only be made during the rainy season according to the navigability of the river this time of year. In the case of cultivated plants, almost all are aware of the researchers, so that their scientific nomenclature is easier to determine. Records are made in daily field notes in notebook, photograph, design sketches and GPS device.

\section{Field Data-Collection and Analyses}

- Population: the unit reference was the house. It was carried through domicile visits, for family (nuclear or extensive) that inhabits in one same residence, using structured form, where appear the names of the people (Kulina and Portuguese), gender, date of birth, source of the information (documentary or oral), kinship in relation to the "head" of the family and observations.

- Health and sanitation: carried through two complementary methods: direct observation of the village and housings; and semi-structured interviews. The observation was directed for basic aspects of sanitation as: water sources for drinking, cooking, bathing, how to carry and store water, place used for physiological needs, presence, type and location of latrines, structure and material of the houses, type and form of preparation food; breeding, etc. The semi-structured interviews are, basically, toward obtaining data on the diseases/signs/symptoms of highest frequency, prevention and treatment most used. We followed the therapeutic itinerary of health problems witnessed in the field. Therapeutic itinerary is the set of processes implied in the search of a treatment since the disorder verification, passing for all the institucional stages (or not) where can modernize different interpretations (patient, family, community, categories of healers, etc.) and cures [34]. Thus, to each episode of illness, the researcher try to follow and to register all the procedures towards the treatment and the interpretations that the diverse stakeholders involved make throughout the process. To understand a therapeutic itinerary, the concept of "explanatory model" is important. A explanatory model is elaborated for a specific process of illness, having a relation of feedback between the conduction of this process and the notions and explanations that appear throughout the process, in addiction to general beliefs of the culture of the group that exist independently of specific episodes of illness [35].

- Food resource and health: According to the concept of health as the general state of physical well-being, social and spiritual and to process health-illness of Langdon [11, 12], written above, we take in consideration not only the plants considered "remedy", of the biomedical point of view, but all the resources that, in some way, influence the general state of health, including also the animals and plants used as foods and resources with external origin. The data had been collected through direct observation from the Post of Health (when there is one), opened interview with the indigenous agent of health (AIS) and direct observation of all the areas of cultivation (crops) that are called huidsaja in Kulina and roçados in regional Portuguese. It was taken an approximate measure of each huidsaja and the cultivated species was listed. Observation data depend on the season, and then we interviewed the responsible for each huidsaja. 
- Ethnobiological Classification and therapeutical use of the plants: The interviews are carried through in diverse chances and places, whenever convenient, for emic guide. The preferential places choiced were paths to huidsaja. We collected data through participant observation, exploratory and informal interviews, open-ended and depth interviews with key informant (based in emic guide), free list of species, guided tour or walk-in-the-woods, direct observation, and following therapeutic itineraries of illnesses episodes (additional to general diagnosis of the health). In each village, we count on participation of the two or three key informant, generally older people, who demonstrate greater knowledge and legitimacy in the group or with some formal local leadership, the called tamine ("head"), but always followed by other integrant of the village, as adult sons, adolescents or children, even the latter end up providing important data. The informants are not chosen by selection, but for availability, since the number of adults in the villages is small. The information on indication and form of use of each species had been written also in the kulina language with aid of interpreters who, in some cases, had been the primary informant. They had been typed in excel table and inserted in a data base, where they consist: kulina name, common name, scientific name and botanic family (still incomplete), botanical features, indications and methods of use (in Portuguese and Kulina), informant, interpreter, where the plant was found in the village and photos and geographic coordinates.

\section{RESULTS}

\section{Health and Sanitation}

One of the main problems of health and sanitation in the villages is in regards to water sources used for various needs, such as food preparation, drink and to bathe. The main water source is the river itself. In some villages, the Kulina constructs small water reservoirs in narrow riverbanks or next to water springs. These reservoirs are known regionally by cacimbas (small water tank dug near water sources). However, at rain season (between November and March), cacimbas are submerged or dirty, since the pluvial waters load all type of residue for their interior. At the time of dry weather (April to October), cacimbas dry or are with low capacity, depleting quickly due to demand of the population for water. The majority of the villages are just on the edge of the river. In these cases, the people use its water directly to take bath, to prepare foods and to even drink without any treatment. The bath is taken, generally, only with water, as much in the river, the stream or cacimba. Soap is a rare product and depends on acquisition in the city, what is made with the scarce resources of the few pensioners, professors or when wage-earning health agents, therefore nor all have written contract with the responsible institutions of these last ones, State Secretary of Education of Acre and Funasa (National Health Foundation) respectively.

The water is loaded in any container, generally pans. The girls participate of this task since four or five years old, training their capacity to balance this load on the head and her legs to support the weight when going up the abrupt declivities. The water that is loaded from the river, igarapés (streams) or cacimbas, when it is not used immediately, is stored in these same containers. With a mug or cup, they serve themselves with water.

For handing wash and clean some dirty inside the house, they usually put water in their mouth and eject it, serving the mouth as tap. In general, the cleanness of the house is made with vegetable fiber broom and, eventually, some women wash the wooden floor.

The foods are prepared in simple way. Generally, they are cooked or baked. In each housing, there is a "fire" (hearth), which is almost constantly lit. The fire and its maintenance, as well as the preparation of foods, are feminine tasks. It has a typical standard in the disposal of the burning woods and that keep the fire permanently lighted, without raising flames, and that allow they puting the pans directly on the fire, supported in the convergence point of some woods. These are arranged to form a circle, with one of the tips converging to the center, where starts the fire. To bake, depending on the situation and the type of food, they put the food directly on the fire or on a grate of wire.

The consumption of food is done with the bare hands, without use of tools such as cutlery. Sometimes they put the food in a dish, where they serve. Other times, derive directly from the pot or, when baked, the fire or the grill.

In the summer time (dry season) the Kulina spend part of their time camped in the beaches that are formed throughout the river. There, they built small shelters with wood and straw, they fish, hunt, prepare their foods and, after some time, they change for another spot of the river. The river becomes the main source of food and water. During that season the river has less volume.

The physiological needs are made in the woods, around the village. With regard to children, this distance is not usually observed. In one village (Nova California), Funasa built a sanitary annex to the building of the school. However, the hydraulic installation was never concluded and the building was abandoned and dilapidated. Moreover, the change of habit does not only depend on the construction of toilets, as show other experiences.

The majority of the houses are constructed following standard model of the old houses of rubber tapper's of the region. They are relatively small (varying of 10 a $50 \mathrm{~m}^{2}$ ). First, they assemble a structure with resistant wood, with four or six vertical columns connected by horizontal rods with smaller diameters, tied with envira (bark of certain trees) and using techniques for fitting. For in such a way, they use the leaves of various species of palms previously prepared by drying them laid out. The straw leves are placed one to one, following from the eaves to the top, and tied with envira in the structure of the covering. The wooden floor is mounted approximately $1 \mathrm{~m}$ above the ground. Both the floor and the walls are generally of the stem bark of paxiúba (Iriartea deltoidea Ruiz \& Pav., Arecaceae). Rarely there are divisions in the house. At the highest point of the house, the space can be used to save the few personal belongings, seeds, or even to arm hammocks.

The Kulina sleeps in hammocks. As in the region there are many insects, mounting protection for hammocks is required. They are called mosquiteiros (mosquito nettings). These are made by women using fabrics purchased in the 
city of Feijó. In addition to protecting against insects, the mosquito nettings create small spaces of privacy inside the houses. Through times, mosquito netting protects more than one hammock. The hammocks are ween by the Kulina, from cotton cultivated by them, or are bought in the city. Even during the Day, when they are inside the house, they costume to be under the mosquito nettings, only place where it is possible to exempt of the so abundant mosquitos.

Water-borne and food-borne illnesses and acute respiratory infections are most prevalent among the Kulina. Among the first ones, the diarréias (mimiji) are distinguished, mainly among children, and verminosis (ssomi). Other important problems are headake, snakebites, injuries during activities in the crops (mainly in the stage of slash and burn) and in the forest (during activities of hunting), damages resulting from internal conflicts and dermatosis in general. From the 203 indications of remedies registered so far, 48 are for external use (injuries, snakebites, scorpions, spiders, stingrays, ants and other animals accidents, pains and skin problems in general), 20 are for digestive system problems (diarrhea, worms, stomachache, toothache, pain in general, and oral candidiasis), 12 for headache and eight for respiratory infections in general (flu, cough, phlegm and one for tuberculosis) (see Tables $\mathbf{1}$ and $\mathbf{2}$ ).

A problem strict on the cultural questions of the Kulina is the mutual accusations of dori among members of different villages. Dori is an ethiologic category provoked by shaman (dsopineje). Each village has one or more shamans. They act in such a way in treatment and cure as well as are, constantly, accused to provoke dori, problem that needs to be solved by another dsopineje. This type of problem manifests itself in different ways, physics or psychological, in the victims. We witnessed shamanic ritual during our fieldwork when several dsopineje were treating woman that was victim of dori. The session lasted about four hours. Each dsopineje came from the forest wearing skirt made of new leaves of ivory plant, a palm called jarina in Portuguese and dsiqui in Kulina language (Phytelephas macrocarpa R. and Phytelephas microcarp $\mathrm{R} \&$ Pav.). In a yard, to the side of the houses, young women dance in semi-circle in order to support the xamãs. Each dsopineje dance in front of them and after act on the victim's body, sucking the dori, the material form of it, like a little stone or other object. After symbolically expel the cause of dori, they cause vomiting and spitting into the bank of the river, or out of the home environment. This procedure is repeated several times.

The therapeutic itinerary depends on the available options and that are more easily accessible to the population. Among the Kulina from the Upper Envira River, due to isolation from the city, where are the official health services, resources are limited practically to those available in the forest, that are of their knowledge, in addition to the activity of shamans. The cases monitored in field demonstrate clearly the pragmatic character of the curative measures. The first step is to appeal to the members of the family, generally to the most experienced. After that, they search aid of other members of the village. Only serious cases and provoked by strange sources to the kulina universe are sent directed to the city of Feijo or to the capital of the State of the Acre, Rio Branco. In our fieldwork, we observed two cases that were referred to Feijó and one of them was to Rio Branco. One case was an elder that had been suffering from diarrhea for weeks and not feeding properly. He was in the Igarapé do Anjo village, the most distant one, visiting his son, who is tamine (head). To make the trip to Feijó, they had before to hunt and gather enough food, since the trip lasts several days of sailing a canoe without engine. After about two weeks down the river past the old man succumbed and died. He was buried on the riverbank. The Health Agent, in this case, acts only as responsible for routing and transport the patient. However, he does not have any resource for this work. The second case referred to the city was a man victim of shot of firearm during an internal conflict in a village, during a section of caiçuma beverage, a traditional alcoholic beverage prepared from small-scale fermentation of cassava (Manihot esculenta Crantz). He was wounded at night, but they had start down the river just in the following morning, taking several days to reach Feijó. From there, he was referred for treatment in the capital, Rio Branco, where there is the House of the Indian Health. He returned to the village after a long period of recovery.

The illness-treatment-cure process is dynamic, depends on interpretations that vary as new signals and symptoms appear and, thus, the etiologic categories will also be modified. Depending on the case, it can have accusation of $d o r i$, in general, to one dsopineje of another village. In this case, there may be a shamanic ritual, which can count on the participation of one or more dsopineje. Even in the case of snake bite, the Kulina resist in the village itself, treating the patient with their medicinal plants. So far, we registered eight plants indicated to treat snakebite. Some are specific for certain species of snake. After our departure of one of the villages (Salão), in 2008, we knew that the taminé had been bitten by a snake pit viper (Bothrops sp.). He remained in the village and, in the second trip, in 2009 , we realized that he was very good health.

\section{Food and Health Resources}

To treat their health problems, the Kulina of the Upper Envira River have the own local resources immediately and the official services of health that are distant and difficult to access. They include the plant resources of the forest or cultivated around the houses, such as fruits and medicinal plants. Among the latter, there are several that are known and are not native to the region, as mint (Mentha spp), mango (Mangifera indica L.), cacao (Theobroma cacao L.), ginger (Zingiber officinale Roscoe), basil (Ocimum sp.), citrus (Citrus spp.), chive (Allium sp.), coconut (Coconuts nucifera L.), sugarcane (Saccharum officinarum L.), which are brought in when a trip was made by some members of the village, or simply the time of introductioin is unknown, considering the fact that the region was occupied by nonIndians since the end of the nineteenth century. There is exchange of seeds and seedlings between the Kulina and neighbors (Ashaninka, Kaxinawá and cariu). There is constant interchange with kulina villages from Purus River, because they know the forest paths (varadouros) they use to cross, allowing exchange of visits between residents of two rivers, which can last several days of trekking through the forest.

Most of the therapeutic resources of the Kulina are obtained in the forest. They know hundreds of species for 
different purposes. The domain of this knowledge is among the oldest, but much is shared among the members of the village. Even adolescents are able to point to different species and explain its purpose and mode of use. We found some variations in knowledge between villages for similar species. Some informants highlight differences between their knowledge and the Kulina of State of Amazon.

The official services of health are represented by the structure and health professionals of public health. Since 1999, the National Health Foundation (Funasa) is the institution responsible for the health of indigenous peoples, part of Brazilian universal public health system (SUS). SUS is formed by networks of health local, state and national levels. The flow of care should follow, by level of complexity, from the Post of health to more specialized hospitals.

There is a subsystem of indigenous health linked to Funasa, dividing the country into Indigenous Special Local Health Districts (DSEI). Each DSEI has several Pole Bases, which are physical structures where there is a health team responsible for the care of the indigenous population of one or more municipalities. In Rio Branco, capital of Acre State, is the House of the Indian Health, to where they are referred patients with unsolved problems in the municipalities. There, they are hosted and receive basic care while transiting in the Units of Health of greater complexity in Rio Branco. Highly complex cases should follow to other states. In the villages, there are the Indian Health Agents (AIS). They participate in courses of the Funasa, but not all are employed. For Kulina, AIS category is more symbolic than practical, since they have no structure or technical training to take care of the problems that appear, as already exemplified above. Another issue is the legitimacy of AIS in front of others villagers. Their role, in most cases, is restricted to monitor seriously ill patients to the Pole Base in the city of Feijo. Thereafter, the patient flows through the network of public health.

Kulina diet is basically composed of carbohydrates and animal proteins. The base of the feeding is the cassava or manioc (Manihot esculenta Crantz) and the banana (Musa paradisiaca L.). The Kulina cultivate and manage several varieties of these two species in their crops (huidsaja). The advantage of cassava is that it can be kept year-round on huidsaja and be taken whenever necessary. The banana produces year-round in the Amazonian climatic conditions and can be maintained even in old huidsaja for several years.

In general, the productive activities (huidsaja, hunting, fishing and gathering) of the Kulina are performed independently by each nuclear family that shares the same residence. Practically all huidsaja had been visited in the two field trips, totalizing more than fifty, from the biggest to the smallest. The huidsaja are generally destined especially to the cultivation of ritual and toxic species, such as tingui (several unidentified species used for fishing) and tobacco (Nicotiana tabacum L.), although these species can be found in any huidsaja.

The huidsaja are implanted and maintained following a particular agricultural calendar, according to the regional seasonality and the culture of the group. Around May, they choose an area of forest and begin to "drill" (brocar in regional Portuguese), that is, cut only the lower stratum of vegetation such as herbs, vines and small shrubs. Around July, they knock down the larger scale species. They wait to dry the vegetation and in August and September they concentrate to burn these areas. Whith the onset of the rains begin, they start planting. They usually do one or two weedings per year.

The Kulina's huidsaja are relatively small. Most is only 1 ha In its small size, the fields may hold more than ten cultivated species. We can classify them as sucessional huidsaja, in that the species are intercalated, throughout its implantation and maintenance, until reaching the stage when they are "abandoned". Huidsaja starts, then the succession of species that pass through the stages of capoeira (secondary vegetation that can be originated from the degradation of several possible vegetation types) and secondary forest. Despite the use of fire, these huidsaja are sustainable environmentally due to the small dimensions, and as soon as "abandoned", after the fourth or fifth year, quickly occur the forest regeneration.

The huidsaja include food, medicinal and ritual plants and fibers, thus they are important units for the food safety, as source of medicinal and ritual plants, cotton, inks and fibers. Therefore, the kulina health, on a general way, depends on huidsaja. The most important species in the huidsaja are: cassava, banana, papaya (Carica papaya L.), maize (Zea mays L.), Sweet-potato (Ipomoea batatas (L.) Lam.), tobacco, cotton (Gossypium hirsutum L.), urucum (Bixa orellana L.), cará (Dioscorea sp.), taioba (Colocasia spp. and Xanthosoma spp.), sugar cane (Saccharum officinarum L.), some species of tingui, pineapple (Ananas sp), pumpkin (Cucurbita spp.), watermelon (Citrullus vulgaris Schrad), peppers (Capsicum spp.), ingá (Inga spp.), rice (Oriza sativa L.), cubio (Solanum sessiliflorum Dun.) and other rarer ones. Among these species, diverse etnovarieties can be found. Thus, foods can vary depending on the quantity and diversity of cultivated plants.

In the dry seaosn, when big beaches are formed in the edges of the Envira River, the Kulina also use these spaces to cultivate some species. After the flood, great amount of organic substance is deposited in the sand. In these sazonal huidsaja, beans (Phaseolus sp.), watermelon and maize predominate. Before the rainy season starts again, the reproductive cycle was already completed. The advantages to use beaches are easiness to grow, therefore does not demand any preparation of the area, it is easy to reach, coming easily paddled their canoes.

In addition to cultivation, there is gathering fruit in the forest, depending on the season. Among these are distinguished: açai (Euterpe precatoria Martius), palm buriti (Mauritia flexuosa L.), palm patoá (Oenocarpus bataua Martius), cajá (Spondias sp.), cajarana (Spondias sp.) among others. All these fruits are important sources of micronutrients such as vitamins and minerals. However, in the day by day, these fruits do not even have significant weight in the kulin feeding. These gathereing are sporadic and depend on the time of fruiting of each species.

A very important factor for the health of the Kulina is the proteinic ingestion based in the hunting and fishing. To be considered strong and healthful, a kulina must eat fish and hunt meat frequently. The Kulina are traditionally hunters 
and theirs ethno- ecological knowledge allows to know where and when to find each animal and to choose the best strategies of hunting. Currently, beyond the traditional weapons, as bow and arrow, they use firearms. However, they do not always have ammunition. Some men stand out as hunters and play an important role as providers of meat. When they arrive from hunting, they are received by the women. These, generally, are responsible for prepare the hunting, baking and to distribute the meat.

The more important species as hunting are collared peccary (Tayassu tajacu L.), white-lipped peccary (Tayassu pecari Link), deer (Mazama spp.), tapir (Tapirus terrestris Briss.), capibara (Hydrochoerus hydrochaeris L.), several species of primates and other smaller species such as paca (Agouti paca L.), agouti (Dasyprocta agouti L.), tortoise (Testudo sp.) and turtle (Podocnemis sp.). The caiman (Caiman spp.) also is very aimed by the Kulina, that they cited at least three types. The caimans are hunted at night with use of harpoon or firearm. The birds also are important in the kulina diet, but they are hunted in lesser ratio. Generally, they are second option, therefore they do not compensate the effort in the same way that a large animal.

Fishing is a routine activity and it represents a food source more affordable and that requires less effort than hunting. However, it depends on the season of the year, due to water levels, the availability of lakes near the village and appropriate fishing instruments and in good condition. These are relatively expensive or demand time and ability to handmade. A good fishnet or trawl fishing can take months to complete. Fishing with line and hook is an activity generally relegated to the children and depends on the acquisition of hooks, nor always accessible. Another technique is the use of somes species of plants called tingui, which are hit into the water and poisoning the fish, causing them to float. It is most common in igarapés (small rivers or streams).

Animal husbandry is an incipient activity. Depending on the village, some introduced domestic species are created, as swines (Sus domesticus), catlle (Bos sp.), sheeps (Ovis sp.), hens (Gallus gallus domesticus), and dogs (Canis familiaris). Dogs are used to assist in the hunting or as animal of esteem. In some villages, the inhabitants had decided do not create pigs and bovine cattle due to the damages that they cause. These animals invade huidsaja, destroy the bush and harm the varadouros. Various native species of the forest can be found in a kulina village. Generally, these are younglings of hunted animals that are brought home and become common elements in the domestic daily. Some younglings can be, also, breastfed by women.

\section{Etnobiologic Classification and Therapeutical Use of the Plants}

There are no specific words in the kulina language to label animal or plant as generic categories, but we can observe that this taxonomic differentiation exists. In this case, we can consider categories such as hidden or unnamed. In the Kulina ethnotaxonomy predominate more specific categories, so that they know and nominate many species, with few broader categories.
With regard to animals, using free-listing interview technique, a group of six men, in an only session, had been cited 126 species between insects, mammals, birds, fishes and reptiles. For each cited species, with few exceptions, the name in the kulina language and regional Portuguese was indicated.

Our work, however, is focused on plants for therapeutic use. In this regard, we highlight the species listed by the technique of guided tours held on trails in the forest with the help of two or more Kulina informants. Thus, 193 ethnospecies or landraces named were cited in the kulina language and its use and purpose. Among these, most are herbs, shrubs or lianas, indicating that the stratum below the forest, which is more within sight and is more accessible, is the most important source of therapeutic resources. In addition to these species, there are those already mentioned above, grown in the huidsaja or in the peridomestic space. We believe that this number is higher, considering that the work is still in progress.

At the IL Kulina do Rio Envira, located further up, had been registered 55 (ethno) species; Jaminawa-Envira, had been 64; and, at the IL Kulina do Igarapé do Pau, had been 76. All the indications and modes of use had been written in Portuguese and Kulina languages, aiming to elaboration a printed matter destined to the group itself. The nomenclature can vary from one village to another. An observed detail is that, practically, it does not have fixed names for the species. The nomenclature can be descriptive, detailing morphologic, ecological or utilitarian aspects of each species. Thus, the name of a species may vary according to perception and knowledge of each kulina. Almost all of these species has no known name in Portuguese by the researcher or by the Kulina.

From an ethical point of view, we can group the plants for therapeutic use according to the type of problem it is intended. Thus, plants can be used for signs and symptoms of the nervous system, mainly headache; digestive system, primarily diarrhea and worms; respiratory system, especially fever and flu; for external use, such as skin, injury in general and especially for ophidians accidents. In addition to these physical or organic problems, there are many species that can be used to achieve success in sex, dating or marriage. Also, there are some mentioned ethnospecies intended to promote health, serving as a "vitamin" or to gain strength and get stronger, work harder and so on. In Table 1, the numbers of indications for general category of use are specified. As there are more plants than indications of use, the registered citation number exceeds of ehtnospecies.

In the categories "curative action (diverse)" and "Preventive action", we group the indications in general without the indicated for accidents with animals, which appear separate. In Table 2, these two categories are analyzed according to purposes of specific uses as the indications at the moment that each plant had been shown. We group these specific purposes in accordance with the corporal system where they should act more directly. The total of specific uses (78) is less than the total of the two categories (83) because there are overlappings of five plants that fit into two categories. 
Table 1. General Categories of Use of the Plants Cited by the Kulina and Number of Citation Per Category (n=195)

\begin{tabular}{|c|c|}
\hline Category of Use & Cited Numbers and Percentage of Ethnospecies \\
\hline Curative action (diverse) & $71(36,41)$ \\
\hline Magical/ ritual & $53(27,18)$ \\
\hline Preventive action & $12(6,15)$ \\
\hline Tonic/stimulant & $12(6,15)$ \\
\hline To feed & $12(6,15)$ \\
\hline Foods for animals of the bush & $11(5,64)$ \\
\hline Ofídic accident & $8(4,11)$ \\
\hline Accident with spider & $3(1,54)$ \\
\hline Accident with stingray (fish of class of the Chondrichthyes) & $3(1,54)$ \\
\hline Insecticide/poison & $3(1,54)$ \\
\hline Accident with scorpion & $2(1,03)$ \\
\hline Accident with tucandeira (Paraponera clavata), an Amazonian ant & $2(1,03)$ \\
\hline Accident with poisonous caterpillar & $1(0,51)$ \\
\hline Dog bite & $1(0,51)$ \\
\hline Accident with mambira or tamanduá-de-coletete (Tamandua sp.) & $1(0,51)$ \\
\hline
\end{tabular}

In magical/ritual category, we include all the plants that, according to Kulina, can be used in interpersonal relations, such as to dating, to have sexual relations, to steal the woman of the other, to hold husband, to exchange woman when someone is boring of her, to kill an enemy and so on (16 citations), to get success in the hunting (15 citations), for use in the ritual of consumption of the liana jagube (seven citations), to control the weather/meteorology (five citations), for dsopineje to provoke dori (four citations), to improve the macaxeira production (two citations), for specific use in children (two citations), to improve fishing (1 citation) and to take off laziness (one citation).

In the interpersonal relations, the cited modes of use for these purposes had been mix to perfume, to carry in the pocket, to smell the leaf and to prepare a remedy to use in the woman or in the man.

With regard to the hunting, the indications are most diverse, always in the direction to get success, to have luck or to take off "panema", that is a badluck condicion attributed to the hunters, in all the Acre region, when they are for long periods without good results in the activities of hunting. There are plants to help to kill tapir, to catch jabuti, to kill white-lipped peccary, to dog become "marupiara" (good to hunting) and to hunt several species in particular. The ways to use plants also vary to each case, such as: to rub in the snout of the dog; to pass the leaf of the plant in the barrel of the weapon; to carry the leaf in the pocket; to drip the juice in the eye of the hunter; scrape the bark, to mix with the leaf and to blow on of the track of the hunting to it come to the hunter; to rub bark, to mix with the leaf, carry to the woods and blow the dust.
The Kulina know plants that can be added in the beberage that has as base the liana jagube, that they call rami (Banisteriopsis caapi (Griseb. in Mart.) C.V. Morton), and the grass chacrona called sacorona (Psychotria viridis Ruiz \& Pavón) by the Kulina. In addition to these species, the Kulina know others that used in such a way to increase the psychotropic effects of the drink, to reduce it or to have specific visions, according to each occasion. In this sense, they cited seven ethnospecies, which can be mixed in drinks or chewed separately.

The case of the use of plants by dsopineje in shamanic rituals, the plants can help to break a witchcraft or dori. There are plants that dsopineje kneads and smells. These plants help to take off the "stone" (dori) of the body of the sick person. For example, they put the leaf on the region of the stomach, smokes and untied smoke on, later absorbs and the "stone" leaves. Dsopineje also can use a plant in a ritual to kill somebody. They say that this type of plant cannot be chewed because it makes badly.

There are plants used like "remedy" for the cassava (poho). One of these plants must be had the root chewed and spit on the stem of the cassava before planting it. Another plant is used with the purpose to induce the cassava to grow well and to produce thick roots. In this case, it is rubbed the root of the plant in the arm of the planter at the time he/she is planting the steam of the cassava.

There were five citations specifically for children, but only two in the magical/ ritual category. One of them has the specific purpose for child with diarrhea, placing the remedy in the child excrements. In another case, the plant root has to 
Table 2. Specific Purposes of the Plants Fit in the Categories "Curative Action (Diverse)" and "Preventive Action" for Corporal System

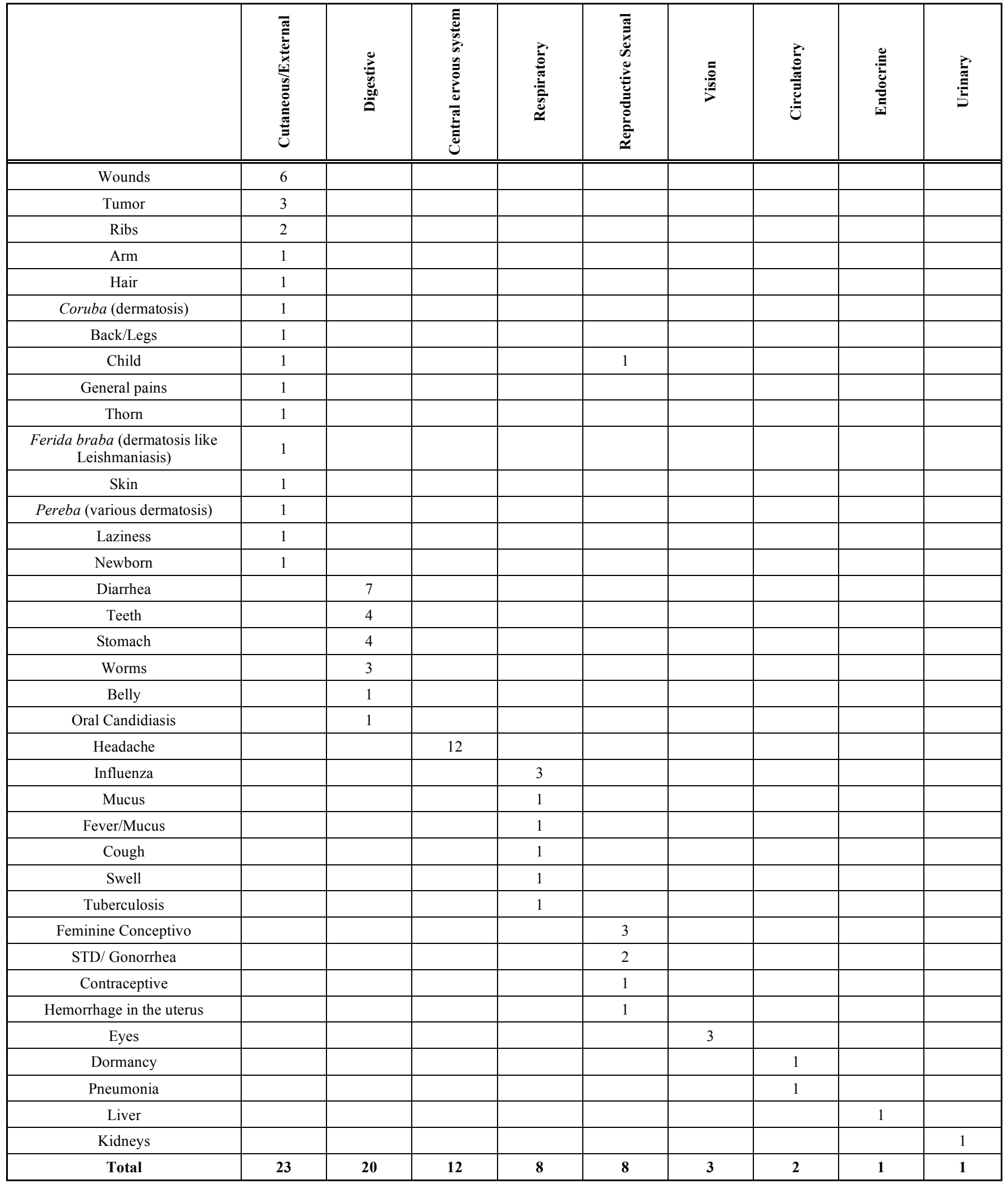

be scraped and rubbed on the penis (dsopori) with the purpose to make the child a sucssesful adult.
The case of magical use to fish, the plant must be rubbed in the hook to have success in this activity. Finally, it has an 
indication of use of a plant that must be dripped in the eye of the person so the person could not be laziness. When, for example, they are in a weighed activity, as to open a new huidsaja, and the sun heat is strong and they fell too lazy, then they drip the plant juice in the eye so that it gives them will to work.

In the category "tonic/stimulant", we include citations of plants used for promotion of desirable qualities. There were two indications directed to stimulate the penian erection. The first case, they rubbed the leaf in the dsopori (penis) and, in the second one, they drink the tea of leafs. Another plant provides speed to the user, which must drip the leaf juice in the eye. Placing the leaves of another plant in hot water, a bath is overcome to make the person stronger and bodily. It also there are a plant that the woman must take its tea to become pregant. Another one is used as coffee, to be awake. There is also a plant to make hair grow faster, it is a liana, which must be beaten, and boiled in the water and after that can be used to wash the head. To the child begins to walk, they use a leaf of another species in their joints. There is also an appropriate plant that woman should use to go to huidsaja.

Among the food, there are plants that take advantage of the fruits of others, roots (potatoes), while others take the leaves to eat. Some fruits are eaten fresh when in activities inside the forest or use to make porridge or juice, crushing the fruit with water. The roots and leaves are cooked or baked, mixed with meat or pure. There are many other plants known by the Kulina and used for different purposes, but we highlight here those that have some relation to health, in general, or with the therapeutic use, in a more specific way.

\section{DISCUSSION AND CONCLUSION}

Analyzing the population pyramid of Kulina people of the Upper Envira River, one cannot affirm that the work load on a few adults is burdensome to the point of compromising the food sustainability of the whole group, for children and adolescents, since an early age, have already the task of searching for food, especially when it comes to fishing and hunting small animals. However, making new huidsaja (by chopping down trees or wildfires) is an exclusive task of adult men (maqquideje), whereas harvesting and transporting food back home from the huidsaja is essentially a female task. In general, hunting is practiced by men from adolescence on (dsabisso). The population growth, with high birth rate, however, brings, as a consequence, a broader autonomy for the children [36].

On the other hand, the pyramid's wide base and the narrowing of bands representing aged people denote a high birth rate, but low life expectancy. However, it is imperative to examine the recent history of IL land demarcation, which occurred in 1980's. Kulina's older generation of people were born in a time when rubber plantation owners dominated and explored them as cheap workmanship. The youngest generation was born in the demarcated IL, when they started to master their territory, having security to take advantage of the forest resources and to cultivate the huidsaja. A similar process has been observed in other indigenous population, such as the Asurini of Xingu, in the State of Pará, where a population of six people, as observed in 1976, grew to 40 in 1999. A decrease in the age group of young and adults alike could be observed, confirming an imperfect demographic pyramid, where the population of up to 10 years of age represents more than $40 \%$ of the group [34], really close to the age group found in Kulina people at Envira River. Population growth is conveyed into physical survival; nevertheless it may represent danger to the IL natural resources [37].

Health and sanitation in Kulina's realm lack a specific public policy, one that is adequate to their socio-cultural and environmental profile. Geographic isolation cannot be counted as a contributing factor to the precariousness of water supply and lack of assistance in health issues, especially as regards to children. The quantity of naturally occurring, good quality fresh water available to each person throughout the world is decreasing daily [38]. This kind of observation tends to be made more for urban regions. No matter the population involved, however, the adequate water supply, in sufficient amount as well as its good quality, is crucial for the local development, and it has a direct impact on health conditions. Ample water supply results in improvement of life conditions as well as controlling and preventing diseases, taking up good habits of hygiene, wellbeing and an increase of life expectancy [39].

The most prevailing diseases among Kulina people are tied closely to the group's sanitary conditions and hygiene standards. The relative isolation saves them from more common health problems found in other indigenous groups, such as the ones in South and Northeast of Brazil, where health conditions are similar to the deprived population in general, among which there is a high prevalence of malnutrition, tuberculosis, dental problems, intestinal parasites, alcohol abuse, high child mortality rate, low life expectancy, etc., not to mention the threat of AIDS [40]. Among the Kulina people, the situation gets worse as the concentration of people increases, fact that is noticeable when we analyze the ratio of houses and householders (5.5 to 1 , on average), given the minuscule size of dwellings and the age, most of them, fifteen years or less. Root [41], in a study on child mortality in sub-Saharan countries, suggests that population density may explain the space variations of child mortality. In the case of current Amazonian indigenous peoples, there is a concentration of population in permanent villages, although the population density is low in this region. It cannot be said that the relative population density is, by itself, a factor that enhances the occurrence of diarrhea, for example, but combined with other factors, it surely represents an increase of exposition to causal agents. Another research [42], in Kenya, testifies that the absence of latrines was a key factor of infection by Ancylostoma hookworms. Dwellings, where soap was nowhere to be found, represented 2.6 times more danger of getting infected by Ascaris lumbricoides if compared to those dwellings where soap was available. The total number of householders was a key factor for infection by Ancylostoma hookworms. The presence of children less than five years of age living in the dwellings was a prognosis for infection by $A$. lumbricoides, whereas their absence was a prognosis for infection by the Ancylostoma hookworm. People in general regard worms not as a serious health problem, but just a 
nuisance, fact that was also observed among the Kulina people.

Public health authorities do not live with the Kulina people and, because of that, they do not know them. The AIS, that had to be the bridge between the population and the public health services, do not have minimum resources, let alone technical apparatus to deal with health problems, which are far beyond the Kulina's cultural realm (kosmos). This reality has been evidenced in ILs of other Brazilian regions, according to Langdon [43]. This indicates that the choice of AIS, the alternation of occupations, the relationships within the crew and between the latter and the community, as well as the relationships between the indigenous community and services outside IL, are branded by local issues with social, political and cultural powers that pressure the good functioning of health subdivisions as a whole. Langdon conclude "that the provision of differentiated care is precarious and that a dialogue is necessary, with actual participation by all stakeholders in the health services." Among the Kulina population, the geographic and cultural gap seems to be even bigger in this regard.

The Kulina people practice traditional medicine with vast knowledge on therapeutical resources of their own, which are basically plants in the forest. This corpus is shared between the members of the group, even though some, admittedly, are more experts than others. This rich knowledge has been demonstrated to the most diverse Amazonian indigenous groups [44-50], also in relation to medicinal plants introduced [51]. In this context, Kulina shamanism can be found, and it has to do with problems related to dori, that can be translated by "witchcraft", represented by invading substances, also called dori, that provoke diverse signs and physical symptoms, but also threaten people's lives, as already described by Pollock [52, 53]. Shamanism is an important institution among South American Indians, expressing their general concerns [54]. More encompassing analysis has been made when it comes to shamanism, and the one practiced in South America gets prominence. In this regard, Eliade [55] affirms that South American shamans know the medicinal properties of plants and animals, but, due to the spiritual origin of the diseases, according to their understanding, it is imperative to turn to shaman healing. We noticed that innumerous plants, according to the Kulina people, are used exclusively in the practice of shamanism. Also, we witnessed a healing ritual involving several shamans. In this case, not only the ritual itself but also the usage of medicinal herbs are elements of a process that involves the Kulina notion of etiology and nosology of certain illnesses. Dori is an essentially Kulina cultural element and it is related to the repeated internal conflicts of the group.

Cultural backgrounds where many forms of therapies or 'medicines' coexist have been treated as the concept of 'medical pluralism.' The establishment and usage of this concept in anthropological literature is discussed by Buchillet [34]. According to the author, the first concern, when sick, tends to be the relief of the symptoms. Throughout the treatment, symptoms and causes of the disease are dissociated. The shaman healing process could be concen- trated on the ultimate cause of the infirmity, that is, "why me?" and "why now?", but within a particular social and cultural sphere. The usage of medicinal plants, other traditional resources, as well as the western medicine focus on the effects. Thus, a health professional might consider a patient healed. By the principles of shamanism, not necessarily the shaman's own, however, healing may not have occurred, requiring a solution for the ultimate cause. Fausto [56], for example, could see that talking about shamanism for the Parakanã people - a Tupi-guarani speaking tribe in the State of Pará - implies, before anything has been understood, the absolute non-existence of shamans. This assignment, rather than being an honor, was a disgrace. As a result, accusation and witchcraft were the means in which the Parakanã people explored this subject. This is very similar to what happened to Kulina people because the dsopineje, who is also blamed of practicing witchcraft, has a paradoxical personality. It's through him, however, that a victim of dori is healed. Since shamanism is an important component of the Kulina culture and the dori is a causal agent, being oftentimes targeted, a disease assessment in this context is felt necessary.

Follér [57] analyzes the 'zone of contact' where biomedicine and the traditional indigenous knowledge interact in theory and in practice. He uses the concept of intermedicality, term initially used by Greene, when discussing shamanism among the Aguaruna. For Greene [17], intermedicality is a contextualized space of hybrid medicinal practices and socio-medical conscience. This concept aims to outdo the 'sectorized' vision as it analyzes culture from the praxis standpoint. According to Follér [57], the crossing of different social agencies, representing distinct medical traditions, builds a "dialogical experience," in which everyone is observing and is observed, although a political asymmetry may exist.

It is in this context that a therapeutical program is outlined. The recurrence of a new therapeutical resource each time a problem persists is determined by the conception of repeated or recurrent signs and symptoms and take to the (re)interpretation of the causes of the problem. The assessment of the results in each treatment and the interpretation of the causes will have an impact on the choice of the next resource. For each stage, according to the existing signs and symptoms, the disease may acquire a new label for which a specific cause is attributed. The label is given by an individual person, family, community, or an expert, depending on the period of training of the itinerary. The role of the AIS as well as all the public health system under which all the Kulina are subject are included. The search for the cure is guided basically by the logical of the causality of the illness and the symptoms. There are three steps in the processes of a disease, being (1) the acknowledgement of signs/symptoms, (2) diagnosis and choice of treatment and (3) the evaluation of treatment performed [12]. There is not a mutual agreement on a therapeutical treatment; there is, however, a sequence of decisions and negotiations, because not all share the same interpretations or decisions on a specific therapeutical treatment to be researched.

The relatively high agricultural biodiversity in the huidsaja within the Kulina people is important from the 
standpoint of conservation of agricultural and medicinal genetic materials. The agricultural biodiversity concept emerged in the last 10 to 15 years in the interdisciplinary academic environment involving agronomy, anthropology, ecology, botany, genetics, and so forth. It reflects the dynamic and complex relations, among other things, human societies, cultivated plants and environments where they coexist. Besides, it has repercussions on conservation of cultivated ecosystems policies, promotion of diet and nutritional safety of human beings, social inclusion and local sustainable development [58]. Nevertheless, the diversity of cultivated and collected species does not guarantee a variety in everyday menu. Most of the time, the Kulina people feed almost exclusively on cassava and banana. Although adults display a healthy aspect, we can observe many cases of apparent undernourishment among children and some elderly. This may due to a hierarchical habitual practice during meals, when, as a general rule, adult men help themselves first, then women and children. Observation, however, has proved that there has been a lack of food in some tribes. Deni people, also belonging to the linguistic group of Arawá, between Purus and Juruá Rivers, in the State of Amazonas, also has agriculture as the main food source, whose origin consists of vegetables and carbohydrates [59], being the cultivated species very similar to those cultivated by the Kulina people.

So far, the total of registered species and indications over properties as well as potential usages of each one emphasize an important knowledge from the medicinal standpoint, with a potential for prospection of new bioactive substances. Certainly, a greater amount of species is yet to be registered, thus requiring the continuity of the research. Research among the Deni people [59] also discloses several plants used by the community with pharmacological properties. In this case, the authors deliberately did not reveal certain scientific names for the sake of the indigenous knowledge. As with their counterparts in Kulina people, the Deni shamans (zupinehé) are experts in plants and their properties, but any another Deni can as well know how to use them. The data on the Deni people are comparable to the Kulina in terms of species and their usage. This was already expected due to cultural, linguistic and environmental proximity between them.

What proved to be very difficult in this kind of study was the scientific identification of species. In a biome characterized by high biodiversity, the concentration of individuals of each species is low. The logistic difficulty of collecting and herborizing samples in those field conditions is something else. Tied to these problems, one has to take into account that this is an ethnobotanical research, in which the anthropological element is very important. Thus, the search for species and the data registration depend on accompaniment and information from members of the group, who are experts on plants. Even taking advantage of the walk-in-thewoods technique in the Kulina area, following a trail in the woods, it's almost impossible to record data, take pictures, collect samples properly and yet having to follow the informant because the flow of information is abundant and there are virtually no stops. There are cases in which the informant takes us very far away, sometimes on foot, sometimes on boat, in order to introduce to us a plant that is used, for example, for snakebite. Upon getting there, it happens to be only one sample with a few leaves. The proposal for a solution for this problem is, after demarking the location points of each registered species, to enter in the woods with the exclusive purpose of collecting samples. Even this task will depend on the accompaniment and good will of some members of the group. This demands an excellent relationship between researchers and the group. We seek in our work to match development research activities and the transfer of proper environmental and cultural technologies. This aproach helps us in our work.

We hope that this study contributes to a higher esteem of Kulina's traditional knowledge and, with its systematization, its applicability in projects of self-sustainability allied with appropriately cultural and environmental public policies. Ethnobiology has an important role in the conservation of biodiversity, agrobiodiversity and cultural diversity which, in the case of the indigenous peoples - the Kulina in particular has a close relationship among these concepts. The indigenous health care system is inserted in a larger context, where the concept of intermedicality implies the existence of zones of contact, resulting in new medical realities. Plants are an important element either for one or for the other, but the cultural context of their usage is a key factor to understand their effects.

\section{ACKNOWLEDGEMENTS}

We thank the Kulina People from Indian Lands 'Kulina do Igarapé do Pau', 'Jaminawa-Envira' and 'Kulina do Rio Envira'; The Brazilian Agricultural Research Corporation (Embrapa); the Organization of the Indian Peoples from Envira River (Opire); The National Indian Foundation (Funai); and the Federal University of Acre (UFAC).

\section{REFERENCES}

[1] Parreira JO (Coord.). Atlas geográfico Ambiental do Acre. Rio Branco: Imac (Instituto de Meio Ambiente do Acre) 1991.

[2] Ming LC, Gaudêncio P, Santos VP. Plantas medicinais: uso popular na Reserva Extrativista Chico Mendes - Acre. Botucatu: CeplamUnesp 1997.

[3] Ming LC, Amaral Jr. A. Aspectos Etnobotânicos de Plantas Medicinas na Reserva Extrativista "Chico Mendes". NYBG/UFAC. [Accessed Jun 2007]. Available from: http://www.nybg.org/bsci/ acre/www1/medicinal.html.

[4] Ming LC. Plantas Medicinais na Reserva Extrativista Chico Mendes (Acre): uma visão etnobotânica. São Paulo: Editora Unesp 2006 .

[5] Kainer AK, Duryea ML. Tapping Women's Knowledge: plant resource use in extractive reserves, Acre, Brazil. Econ Bot 1992; 46(4): 408-25.

[6] Shanley P, Medina G. Frutíferas e Plantas Úteis na Vida Amazônica. Belém: CIFOR, Imazon, 2005.

[7] Miranda EM, Sousa JÁ, Pereira RCA. Caracterização e avaliação de populações Nativas de unha de gato [Uncaria tomentosa (Willd.) D.C. e U. guianensis (Aubl.) Gmel.] no vale do rio Juruá-AC. Rev Brasil Plant Med 2003; 05: 41-46.

[8] Klimas C, Raposo A, Wadt LHO, Kainer K. Estudos ecológicos e genéticos para manejo e conservação da andiroba 2007. Embrapa. [Accessed May 2007]. Available from: http://www.cenargen. embrapa.br/cenargenda/noticias2007/agenciaamazonia220207.pdf.

[9] Basso SL. Mitos e Verdades sobre a Pata-de-Vaca - Bauhinia forficata Link. Uma Revisão. Lecta 2002; 19: 7-20. 
[10] Processo $n^{\circ}$ 02000.003320/2006-41, Deliberação n²32, publicado no Diário Oficial da União em 16/12/2008 - Seção 1 - p. 109.

[11] Rodrigues AD. Línguas Brasileiras: para o conhecimento das Línguas Indígenas. São Paulo: Edições Loyola 1986.

[12] Langdon EJM. Representações de Doenças e Itinerário Terapêutico dos Siona da Amazônia Colombiana. In: Santos RV, Coimbra Jr. CEA, Eds. Saúde e Povos Indígenas. Rio de Janeiro: Fiocruz 1994; pp. 115-142.

[13] Langdon EJM. Cultura e processos de saúde e doença. In: Jeolás LS, Oliveira M, Eds. Anais do Seminário sobre Cultura, Saúde e Doença. Londrina: as organizadoras 2003; pp. 91-107.

[14] Pollock DK. Etnomedicina kulina. In: Santos RV, Coimbra Jr. C, Eds. Saúde e Povos Indígenas. Rio de Janeiro: Fiocruz 1994; pp. $143-160$

[15] Toledo VM. What is ethnoecology? Etnoecológica 1992; 1(1): 621

[16] Cabrera A, Incháustegui C, Garcia A, Toledo V. Etnoecologia Mazateca: una aproximación al complejo kosmos-corpus-praxis. Etnoecológica 2001; 6(8): 61-83.

[17] Greene S. The Shaman's needle: development, shamanic agency, and intermedicality in Aguaruna Lands, Peru. Am Ethnol 1998; 25(4): 634-58.

[18] Aquino TTV, Iglesias MP. Kaxinawá do Rio Jordão: história, território, economia e desenvolvimento sustentado. Rio Branco: Comissão Pró-Índio do Acre 1994.

[19] Ziegler-Birraux PV. Ashaninka Shamanic Healing Ritual and Song. The University of Texas at Austin. Arts 1991; p. 113.

[20] Cunha MC, Almeida MB, Eds. Enciclopédia da Floresta. O Alto Juruá: práticas e conhecimentos das populações. São Paulo: Cia das Letras 2002.

[21] Comissão Pró-Índio do Acre. Legumes, frutas, bichos e os índios: a ecologia da floresta. Rio Branco: Comissão Pró-Índio do Acre 1996; p. 74.

[22] Shiva V. Biopirataria: a pilhagem da natureza e do conhecimento. Petrópolis: Vozes 2001.

[23] Ming LC. Plantas medicinais na Reserva Extrativista Chico Mendes (Acre): uma visão etnobotânica. São Paulo: Ed. Unesp 2006.

[24] Capobianco JPR, Veríssimo A, Moreira A, Sawyer D, Santos I., Pinto LP, Eds. Biodiversidade na Amazônia Brasileira. São Paulo: Instituto Socioambiental 2001

[25] Cunha MC, Almeida MWB. Populações tradicionais e conservação ambiental. In: Cunha MC, Almeida MB, Eds. Enciclopédia da Floresta. O Alto Juruá: práticas e conhecimentos das populações. São Paulo: Cia das Letras 2002; pp. 184-193.

[26] Vásquez SH, Yunta ER. Etnoconocimiento en Latino América. Apropriación de recursos genéticos y bioética. Acta Bioethica 2004; ano X, n 2, pp. 181-190.

[27] Acre. Programa Estadual de Zoneamento Ecológico-Econômico do Estado do Acre. Zoneamento Ecológico Econômico. Fase II. Documento Síntese. Rio Branco: SEMA 2006; p. 354. Acre. [Accessed Nov 2009]. Available from: http://www.ac.gov.br.

[28] Povos Indígenas no Brasil. Kulina. ISA. [Accessed Aug 2009]. Available from: http://pib.socioambiental.org/pt/povo/kulina/456.

[29] Verbetes. Ibama. [Accessed Nov 2009]. Available from: http://www.ibama.gov.br/siucweb/guiadechefe/glossario/verbetes.ht m.

[30] A complexidade dos ecossistemas. Floresta Ombrófila Densa Aluvial. Sefloral. [Accessed Nov 2009]. Available from: http://www.sefloral.com.br/ea01052305.htm.

[31] Albuquerque UP, Lucena RFP. Métodos e Técnicas para coleta de dados. In: Albuquerque UP, Lucena RFP, Eds. Métodos e Técnicas na Pesquisa Etnobotânica. Recife: Livro Rápido/NUPEEA 2004; pp. 37-62.

[32] Martin GJ. Ethnobotany: a 'people and plants' conservation manual. London: Chapman \& Hall 1995.

[33] Cunningham AB. Applied Ethnobotany: people, wild plant use \& conservation. People and Plants conservation series. London and Sterling: Earthscan Publications Ltd, 2001.

[34] Buchillet D. A Antropologia da Doença e os Sistemas Oficiais de Saúde. In: Buchillet D, Ed. Medicinas Tradicionais e Medicina
Ocidental na Amazônia. Belém: MPEG/CNPq/SCT/CEJUP/UEP 1991; pp. 21-44.

[35] Haverroth M. O contexto cultural das doenças diarréicas entre os Wari', Estado de Rondônia, Brasil: interfaces entre antropologia e saúde pública. Doctorate Thesis. Rio de Janeiro: ENSP/Fiocruz 2004. Available from: http://bvssp.icict.fiocruz.br/lildbi/docsonline/ 1/6/261-haverkothmd.pdf

[36] Müller RP. As crianças no processo de recuperação demográfica dos Asurini do Xingu. In: Lopes da Silva A, Nunes A, Macedo AVLS, Eds. Crianças Indígenas: ensaios antropológicos. São Paulo: Global 2002; pp. 188-209.

[37] Flowers NM. Crise e recuperação demográfica: os Xavante de Pimentel Barbosa, Mato Grosso. In: Santos RV, Coimbra Jr. C, Eds. Saúde e Povos Indígenas. Rio de Janeiro: Fiocruz 1994; pp. 213 242.

[38] Pereira LS, Cordery I, Iacovides I. Coping with Water Scarcity: Addressing the Challenges. Springer Science+Business Media B.V 2009. Springer. [Accessed Nov 2009]. Available from: http://www.springerlink.com/home/main.mpx.

[39] Razzolini MTP, Günther WMR. Health impacts due to deficient water access. Saúde Soc 2008; 17(1): pp. 21-32.

[40] Langdon, EJ. Diversidade Cultural e os Desafios da Política Brasileira de Saúde do Indio. Saúde Soc 2007; 16(2): 7-12.

[41] Root G. Population density and spatial differentials in child mortality in Zimbabwe. Soc Sci Med 1997; 44(3): 413-421.

[42] Olsen A, Samuelsen H, Onyango-Ouma W. A study of risk factors for intestinal helminth infections using epidemiological and anthropological approaches. J Biosoc Sci 2001; 33: 569-584.

[43] Langdon, EJ. Participation by indians health agents in health services: the experience in Santa Catarina State, Brazil. Cadernos Saúde Pública 2006; 22(12): 2637-2646.

[44] Descola P. La Selva Culta. Simbolismo y praxis en la ecologia de los Achuar. Coleção 500 años, $n^{\circ}$ 17. Quito: Abya-Yala/ MLAL. 1989; 468 p.

[45] Ribeiro B. Os Indios das Águas Pretas. São Paulo: Edusp/Companhia das Letras. 1995.

[46] Tournon J. La Clasificacion de los Vegetales entre los ShipiboConibo. Anthropologica 1991; 9: 119-151.

[47] Brunelli G. La Salud por Medio de las Plantas: Etnobotânica Zoro, Amazônia Brasileña. Am Ind 1987; XLVII(2): 241-268.

[48] Davis EW, Yost JA. The ethnomedicine of the Waorani of Amazonian Ecuador. J Ethnopaharmacol 1983; 9: 273-297.

[49] Milliken W, Miller RP, Pollard SR, Wandelli EV. Ethnobotany of the Waimiri-Atroari Indians of Brazil. London: Royal Botanical Gardens 1992.

[50] Montagner D. Mani Pei Rao: remédio do mato dos Marubo. In: Buchillet D. Medicinas Tradicionais e Medicina Ocidental na Amazônia, Ed. Belém: Edições CEJUP/UEP/MPEG, 1991; pp. 463487.

[51] Bennett BC, Prance GT. Introduced plants in the indigenous pharmacopoeia of Northern South America. Econ Bot 2000; 54(1): 90-102.

[52] Pollock D. Etnomedicina kulina. In: Santos RV, Coimbra Jr. C, Eds. Saúde e Povos Indígenas. Rio de Janeiro: Fiocruz 1994; pp 143-160.

[53] Pollock D. Culina Shamanism. In: Langdon EJ, Bear G, Eds Portals of Power: shamanism in South America. Albuquerque: University of New Mexico Press 1992; pp. 25-40.

[54] Langdon EJ. Introdução: xamanismo - velhas e novas perspectivas. In: Langdon EJM. Ed. Xamanismo no Brasil: novas perspectivas. Florianópolis: Ed. UFSC, 1996; pp. 11-37.

[55] Eliade M. O xamanismo e as técnicas arcaicas do êxtase. $2^{\mathrm{a}}$ ed. São Paulo: Martins Fontes, 2002.

[56] Fausto C. Inimigos fiéis: história, guerra e xamanismo na Amazônia. São Paulo: Editora da USP 2001

[57] Follér M-L. Intermedicalidade: a zona de contato criada por povos indígenas e profissionais de saúde. In: Langdon EJ, Garnelo L, Orgs. Saúde dos Povos Indígenas: reflexões sobre antropologia participativa. Contra Capa Livraria/Associação Brasil Antropol 2004; pp. 129-147. 
[58] Santilli J. Agrobiodiversidade e direitos dos agricultores. São Paulo: Peirópolis 2009.
[59] Pezzuti J, Chaves RP. Etnografia e manejo de recursos naturais pelos índios Deni, Amazonas, Brasil. Acta Amazôn 2009; 39(1): 121-138.

Received: January 05, 2010

Revised: February 17, 2010

Accepted: February 20, 2010

(C) Haverroth et al.; Licensee Bentham Open.

This is an open access article licensed under the terms of the Creative Commons Attribution Non-Commercial License (http://creativecommons.org/licenses/bync/3.0/), which permits unrestricted, non-commercial use, distribution and reproduction in any medium, provided the work is properly cited. 